\title{
Elongation Factor 1-Beta
}

National Cancer Institute

\section{Source}

National Cancer Institute. Elongation Factor 1-Beta. NCI Thesaurus. Code C38962.

Elong ation factor 1-beta (225 aa, $25 \mathrm{kDa}$ ) is encoded by the human EEF1B2 gene. This protein plays a role in the modulation of guanine nucleotide exchange to promote the transport of aminoacyl-tRNA to the ribosome. 